\title{
PENINGKATAN KOMPETENSI PROFESIONAL GURU Mts DDI PADANGLAMPE KABUPATEN PANGKEP MELALUI PELATIHAN PENULISAN KARYA TULIS ILMIAH
}

\author{
IMPROVING PROFESSIONAL COMPETENCE OF TEACHER AT MTs DDI \\ PADANGLAMPE THROUGH WRITING TRAINING OF SCIENTIFIC PAPERS \\ ${ }^{1)}$ Umar Mansyur, ${ }^{2)}$ Ihramsari Akidah \\ ${ }^{1,2)}$ Program Studi Pendidikan Bahasa dan Sastra Indonesia \\ Fakultas Sastra, Universitas Muslim Indonesia \\ Jl. Urip Sumoharjo Km5, Makassar \\ email: umar.mansyur@umi.ac.id
}

\begin{abstract}
ABSTRAK
Tujuan kegiatan pengabdian masyarakat ini adalah untuk meningkatkan kompetensi profesional guru MTs DDI Padanglampe, Kabupaten Pangkep, Provinsi Sulawesi Selatan, dalam bidang penulisan karya tulis ilmiah, khususnya artikel ilmiah untuk publikasi jurnal. Kegiatan dilaksanakan dengan menggunakan metode pelatihan.Pelatihan diberikan kepada 25 guru dan dilaksanakan dalam tiga tahapan, yakni tahap persiapan, pelaksanaan, dan evaluasi. Materi-materi pelatihan yang diberikan mencakup prinsip dasar penulisan karya ilmiah, karakteristik, langkah-langkah, sistematika karya tulis ilmiah, serta praktik penyusunan artikel ilmiah untuk publikasi jurnal. Pelatihan yang telah diberikan kepada guru MTs DDI Padanglampe menghasilkan artikel-artikel ilmiah yang layak untuk disubmit ke jurnal-jurnal. Selain itu, pelatihan ini mendapat respon yang sangat positif dari para guru, karena selama ini mereka masih kesulitan menyusun karya tulis ilmiah.
\end{abstract}

Kata Kunci: Kompetensi Profesional, Karya tulis Ilmiah

\begin{abstract}
The purpose of this community service activity is to improve the professional competence of teachers of MTs DDI Padanglampe, Pangkep Regency, South Sulawesi Province, in the field of writing scientific papers, especially scientific articles for journal publications. Activities are carried out using training methods. Training was given to 25 teachers and implemented in three stages, namely preparation, implementation, and evaluation. The training materials provided cover the essence of writing scientific papers, characteristics, steps, systematic scientific papers, and the practice of writing scientific articles for journal publications. The training that has been given to Padanglampe MTs DDI teachers produces scientific articles that are ready to be submitted to journals. In addition, this training received a very positive response from the participants, because so far they still have difficulty in preparing scientific papers.
\end{abstract}

Keywords: Professional Competence, Scientific Paper

Submitted:4 Mei 2018 Revision: 25 Juli 2018 Accepted:23 Agustus 2018 
Umar Mansyur, Ihramsari Akidah

Peningkatan Kompetensi Profesional Guru MTs DDi Padanglampe Kabupaten Pangkep Melalui Pelatihan

Penulisan Karya Tulis Ilmiah

PENDAHULUAN

Menjadi guru profesional dituntut dengan sejumlah persyaratan, seperti memiliki kualifikasi pendidikan profesi yang memadai, memiliki kompetensi keilmuan sesuai dengan bidang yang ditekuninya, memiliki kemampuan berkomunikasi yang baik dengan anak didiknya, mempunyai jiwa kreatif dan produktif, mempunyai etos kerja dan komitmen tinggi terhadap profesinya, dan selalu melakukan pengembangan diri secara terus menerus (continuous improvement) melalui kegiatan penelitian, organisasi profesi, seminar, dan semacamnya (Kunandar, 2011).

Oleh karena itu, setiap guru dituntut untuk selalu belajar bagaimana menjadi guru yang profesional dan memiliki kompetensi yang mumpuni. Tidak hanya kompetensi dalam proses pembelajaran di kelas, tetapi juga kompetensi profesional dalam bidang penelitian. Senada dengan hal tersebut, Mansyur (2013) menjelaskan bahwa guru secara terus menerus harus belajar sebagai upaya melakukan pembaharuan atas ilmu pengetahuan yang dimilikinya. Caranya dapat dilakukan dengan aktif melakukan penelitian maupun dalam kegiatan MGMP.

Sekaitan kegiatan penelitian, sebagaimana yang diatur dalam Peraturan Menteri Pendayagunaan Aparatur Negara dan Reformasi Birokrasi Nomor 16 Tahun 2009 tentang Jabatan Fungsional Guru dan Angka Kreditnyadisebutkan bahwa untuk kenaikan pangkat jabatan fungsional guru serendahrendahnya golongan III/b diwajibkan membuat karya inovatif berupa penelitian, karya tulis ilmiah, alat peraga, buku, atau karya teknologi pendidikan yang nilai angka kreditnya disesuaikan (Permen PAN-RB, 2019).

Adapun unsur angka kredit jabatan guru yang harus dipenuhiantara lain: (i) unsur pendidikan, (ii) unsur pembelajaran, bimbingan dan tugas tertentu, (iii) unsur pengembangan keprofesian berkelanjutan, dan (iv) unsur penunjang tugas guru. Dari keempat unsur tersebut, satu di antaranya penulisan karya ilmiah untuk publikasi ilmiah sebagai unsur pengembangan keprofesian berkelanjutan.

Pengembangan keprofesian berkelanjutan yang selanjutnya disingkat $\mathrm{PKB}$, mempunyai nilai kredit bagi kenaikan jabatan fungsional guru dan tenaga kependidikan, yang meliputipembuatan karya tulis ilmiah, teknologi tepat guna, membuat alat pembelajaran, menciptakan karya seni, dan mengikuti kegiatan pengembangan kurikulum.Kegiatan PKB dilaksanakan secara berkelanjutan, agar guru dapat selalu meningkatkan profesionalismenya, tidak sekadar untuk pemenuhan angka kredit.

Selanjutnya, kemampuan menulis karya tulis ilmiah (KTI) yang dimiliki seorang guru tentu tidak datang dengan sendirinya, melainkan melalui berbagai pelatihan dan pengalaman meneliti. Bukan hal yang tidak mungkin seorang guru mampu menulis karya ilmiah ataupun artikel ilmiah dengan baik. Penguasaan penulisan karya ilmiah yang terlatih turut mempengaruhi kualitas pendidikan dan lembaga di mana guru tersebut mengabdikan diri, termasuk MTs DDI Padanglampe yang dijadikan sebagai mitra kegiatan pengabdian kepada masyarakat.

Madrasah Tsanawiyah (MTs) DDI Padanglampe beralamat di Jalan Andi Torang No.5 Padanglampe. Sekolah yang berada di bawah naungan Yayasan Darud Da'wah WalIrsuad (DDI) ini berlokasi di Desa Padanglampe, Kecamatan Ma'rang, Kabupaten Pangkep, Provinsi Sulawesi Selatan. Saat ini, MTs DDI Padanglampe telah memiliki peserta didik mencapai 175 siswa, dan dibimbing oleh 25 guru dan 5 pegawai. Dengan jumlah guru yang dimiliki tersebut, MTs DDI Padanglampe tentunya juga dituntut 
Umar Mansyur, Ihramsari Akidah

Peningkatan Kompetensi Profesional Guru MTs DDi Padanglampe Kabupaten Pangkep Melalui Pelatihan

Penulisan Karya Tulis Ilmiah

untuk terus berupaya meningkatkan kualitas dan kompetensi para gurunya.

Berdasarkan hasil observasi yang diperoleh, mayoritas guru di MTs DDI Padanglampe masih banyak yang mengalami keterlambatan kenaikan pangkat. Hal ini disebabkan sebagian besar dari mereka masih kesulitan dalam memahami cara menyusun karya tulis ilmiah dengan baik, seperti dalam hal penulisan artikel ilmiah untuk dipublikasikan pada jurnal, yang merupakan salah satu persyaratan kenaikan pangkat/golongan ke jenjang berikutnya.

Selain itu, juga ditemukan fakta bahwa mayoritas guru di MTs DDI Padanglampe tampaknya kurang berminat/bergelut dalam dunia penelitian. Selama ini, dunia penelitian di sekolah seakan berada pada satu lembah tertentu, sementara aktivitas pembelajaran para guru di sekolah juga berada pada lembah yang lain. Seakanakan ada jurang yang memisahkan di antara keduanya. Hal ini disebabkan kesibukan para guru dalam menyusun rencana pembelajaran dan mengelola pembelajaran di kelas yang selalu mengalami perubahan, sehingga kesempatan untuk mengembangkan keterampilan dalam kegiatan penelitian menjadi terabaikan.

Untuk memenuhi harapan tersebut, maka dilakukan kegiatan pelatihan penulisan karya tulis ilmiah (KTI) kepada guru-guru MTs DDI Padanglampe. Pelatihan ini bertujuan untuk meningkatkan kompetensi profesional para gurudalam bidang penulisan karya tulis ilmiah, khususnya dalam menyusun artikel ilmiah, baik artikel hasil penelitian maupun berupa hasil pemikiran,yang selanjutnya dapat dipublikasikan pada jurnal ilmiah.

\section{METODE KEGIATAN}

Kegiatan pengabdian kepada
Tsanawiyah (MTs) DDI Padanglampe, Kabupaten Pangkep, Provinsi Sulawesi Selatan. MTs DDI Padanglampe memiliki 25 guru dan 5 pegawai. Metode yang digunakan dalam kegiatan ini adalah metode pelatihan. Kelompok yang menjadi sasaran pelatihan penulisan karya tulis ilmiah adalah keseluruhan guru MTs DDI Padanglampe, yakni sebanyak 25 guru sebagai peserta pelatihan.

Pelatihan yang diberikan kepada guruguru yang berasal dari berbagai bidang mata pelajaran tersebut dilaksanakan dalam tiga tahapan, yakni tahap persiapan, pelaksanaan, dan evaluasi. Pada tahap persiapan dilakukan antara lain: (1) observasi ke lokasi mitra pengabdian,(2) mengajukan izin pelaksanaan, (3) persiapan tempat, alat dan bahan pelatihan, serta (4) menyusun jadwal dan materi pelatihan.Selanjutnya, pada tahap pelaksanaan dilakukan antara lain: (1) registrasi guru peserta pelatihan, (2) prosesi pembukaan acara pelatihan, dan (3) pelaksanaan pelatihan penulisan KTI. Adapun pada tahap evaluasi dilakukan penyebaran angket untuk mengukur tingkat kebermanfaatan terhadap kegiatan pelatihan yang telah dilakukan.

\section{HASIL DAN PEMBAHASAN}

Kegiatan pelatihan penulisan karya tulis ilmiah diberikan kepada masyarakat sasar dengan tujuan meningkatkan kompetensi profesional para guru MTs DDI Padanglampe. Dalam pelaksanaannya, disajikan beberapa materi yang memberikan pemahaman dan keterampilan kepada guru-guru mengenai prinsip dasar penulisan karya ilmiah, bahasa Indonesia ragam ilmiah, karakteristik karya ilmiah, langkah-langkah menyusun karya tulis ilmiah, sistematika karya tulis ilmiah, serta teknik penulisan artikel ilmiah untuk publikasi jurnal. masyarakat ini dilaksanakan di Madrasah 
Umar Mansyur, Ihramsari Akidah Peningkatan Kompetensi Profesional Guru MTs DDi Padanglampe Kabupaten Pangkep Melalui Pelatihan Penulisan Karya Tulis Ilmiah

Masyarakat sasar yang menjadi sasaran pada kegiatan ini merupakan sekolah yang berada di lokasi desa mitra binaan Universitas Muslim Indonesia (UMI). Sekolah ini berjarak sekitar $67 \mathrm{Km}$ dari kampus.

Pelaksanaan pelatihan penulisan karya tulis ilmiah bagi Guru MTs DDI Padanglampe dilaksanakan pada tanggal 31 Juli s.d. 1 Agustus 2017. Pelatihan yang berlangsung selama dua hari ini dilaksanakan di Aula MTs DDI Padanglampe.

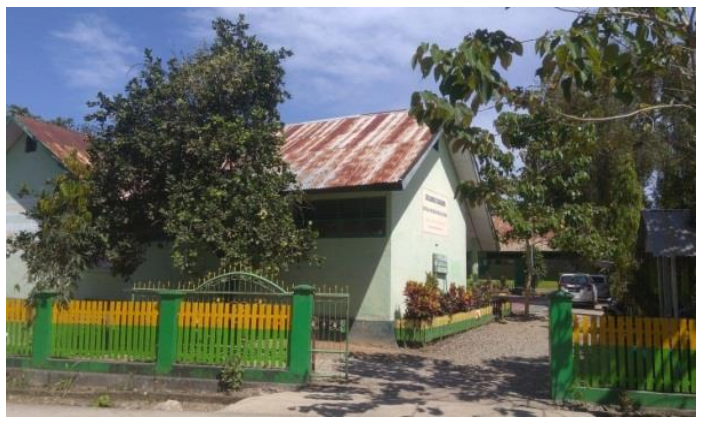

Gambar 1.Lokasi Mitra Kegiatan Pelatihan KTI

Secara rinci, jadwal dan materi pelatihan penulisan KTI dapat dilihat pada tabel berikut.

Tabel 1. Jadwal dan Materi PelatihanKTI

\begin{tabular}{l}
\hline No Tgl/Waktu Materi/Kegiatan \\
\hline Senin, 31 Juli 2017 \\
\hline 1. $08.30-09.00$ Pembukaan \\
09.00-10.30 Prinsip Dasar Penulisan \\
Karya Ilmiah \\
10.30-12.00 Bahasa Indonesia Ragam \\
Ilmiah \\
12.00-13.00 Istirahat \\
13.00-14.30 Karakteristik KTI \\
14.30-14.00 Sistematika Penulisan KTI \\
\hline Selasa, 1 Agustus 2017 \\
\hline 2. 10.30-12.00 Langkah-langkah \\
Menyusun KTI \\
12.00-13.00 Istirahat \\
13.00-14.30 Teknik Penulisan Artikel
\end{tabular}

untuk Jurnal Ilmiah

14.30-14.00 Praktik Menyusun Artikrl Ilmiah Hasil Penelitian

Kegiatan pembukaan acara pelatihan penulisan KTI secara resmi dibuka oleh Kepala Kantor Kementrian Agama Kabupaten Pangkep, yang diwakili Ketua Kelompok Kerja Pengawas (Pokjawas) Madrasah. Selain itu, turut dihadiri Ketua Yayasan DDI Kabupaten Pangkep, Kepala MTs, dan para pegawai sekolah. Kepala Pokjawas Kabupaten Pangkep, H. Sirajang, M.Pd. dalam sambutannya menyampaikan apresiasi dan penghargaannya kepada UMI dan LPMDUMI, serta para dosen dan mahasiswa yang terlibatatas inisiatif dan kerja sama yang semakin bersinergi dan konstruktif.

Para pemateri pelatihan penulisan KTI terdiri dari tiga pemateri, yakni Umar Mansyur, S.Pd., M.Pd. (Universitas Muslim Indonesia), Ihramsari Akidah, S.Pd., M.Pd. (Universitas Muslim Indonesia), dan Abdul Haliq, S.Pd., M.Pd. (Universitas Negeri Makassar).

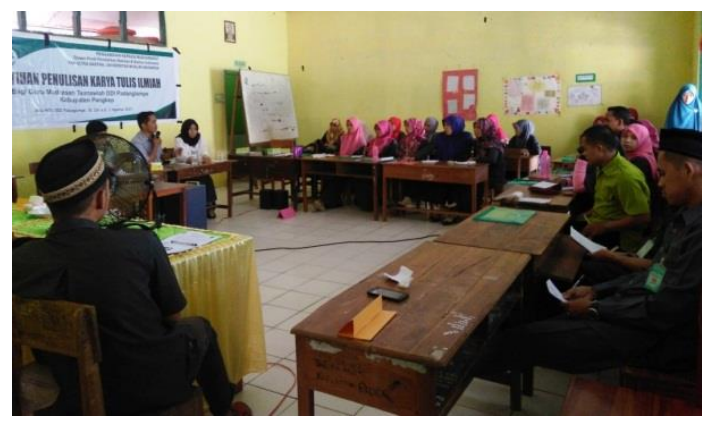

Gambar 2. Suasana Pelatihan Penulisan KTI

Khalayak yang direncanakan menjadi peserta pelatihan sebanyak 25 peserta. Namun, pada saat kegiatan berlangsung, peserta yang hadir mencapai 23 guru. Dengan demikian, secara persentase dapat dikatakan bahwa peserta yang hadir mengikuti kegiatan 
Umar Mansyur, Ihramsari Akidah

Peningkatan Kompetensi Profesional Guru MTs DDi Padanglampe Kabupaten Pangkep Melalui Pelatihan

Penulisan Karya Tulis Ilmiah

pelatihan penulisan KTI terpenuhi hingga 92\%. Ketercapaian target dari jumlah peserta yang direncanakan tidak terlepas dari komunikasi yang dibangun sejak awal oleh tim pelaksana dengan Kepala MTs DDI Padanglampe dalam menentukan waktu dan format pelaksanaan kegiatan, sehingga kegiatan dapat berjalan dengan efektif dan efisien.

Pelatihan yang telah diberikan kepada guru MTs DDI Padanglampe menghasilkan artikel-artikel ilmiah yang layak untuk disubmit ke jurnal-jurnal. Selain itu, pelatihan ini mendapat respon yang sangat positif dari para guru, karena selama ini mereka merasa masih kesulitan menyusun karya tulis ilmiah.

Selanjutnya, evaluasi dari pelatihan penulisan karya tulis ilmiah yang telah diberikan kepada guru MTs DDI Padanglampe dievaluasi berdasarkan taraf respons peserta mengenai kebermanfaatan kegiatan pelatihan yang telah diikuti. Data tersebut diperoleh dari hasil kuesioner yang disebar kepada peserta yang telah mengikuti pelatihan. Hasil tabulasi data skor kuesioner yang telah diperoleh diklasifikasi ke dalam empat kategori respons, yaknisangat bermanfaat (SB), bermanfaat (B), kurang bermanfaat $(\mathrm{KB})$, dan tidak bermanfaat (TB), yang secara rinci hasilnya dapat dilihat pada tabel berikut.

Tabel 2. Klasifikasi Skor Kuesioner Respon Peserta Pelatihan KTI

\begin{tabular}{cccccc}
\hline No & Interval & Kategori & Nilai & $\mathrm{f}$ & $\%$ \\
\hline 1. & $86 \%-100 \%$ & SB & $46-54$ & 14 & 61 \\
2. & $66 \%-85 \%$ & B & $36-45$ & 9 & 39 \\
3. & $36 \%-65 \%$ & KB & $20-35$ & 0 & 0 \\
4. & $0 \%-35 \%$ & TB & $0-19$ & 0 & 0 \\
\hline & & & Jumlah & 23 & 100 \\
\hline
\end{tabular}

Berdasarkan Tabel 2 diketahui respon peserta menunjukkan bahwa dari keseluruhan peserta yang telah mengikuti pelatihan, terdapat 14 peserta atau sebanyak $61 \%$ memberikan respons kategori sangat bermanfaat, dan 9 peserta lainnya atau sebanyak 39\% memberikan respon kategori bermanfaat. Hasil ini selaras dengan fakta yang terlihat di lapangan selama kegiatan pelatihan berlangsung. Para peserta tampak bersemangat memperhatikan materi yang disajikan. Selain itu, pada sesi tanya-jawab, peserta juga antusias memberikan pertanyaan dan tanggapan kepada pemateri.Mayoritas peserta menganggap kegiatan pelatihan yang diberikan mampu meningkatkan kompetensi profesionalitas mereka, terutama dalam menyusun artikel ilmiah untuk publikasi jurnal.

Dengan demikian, berdasarkan gambaran mengenai hal di atas dapat dikatakan bahwa pelaksanaan kegiatan pelatihan penulisan karya tulis ilmiah dapat meningkatkan kompetensi profesional guru MTs DDI Padanglampe Kabupaten Pangkep.

\section{SIMPULAN}

Berdasarkan hasil pelaksanaan Pelatihan Penulisan Karya Tulis Ilmiah bagi Guru MTs DDI Padanglampe Kabupaten Pangkep, dapat disimpulkan bahwa kegiatan berjalan dengan lancar. Selain itu, pelatihan yang telah diberikan menghasilkan artikelartikel ilmiah yang layak untuk disubmit ke jurnal-jurnal.

Pelatihan yang dilaksanakan juga mendapat respon yang positif dari para peserta. Hal ini dibuktikan dari hasil kuesioner yang disebar kepada peserta yang menunjukkan bahwa dari keseluruhan peserta yang telah mengikuti pelatihan sebanyak $61 \%$ memberikan respons kategori sangat bermanfaat. Dengan demikian, kegiatan pelatihan penulisan karya tulis ilmiah ini dapat meningkatkan kompetensi profesional para 
Umar Mansyur, Ihramsari Akidah

Peningkatan Kompetensi Profesional Guru MTs DDi Padanglampe Kabupaten Pangkep Melalui Pelatihan

Penulisan Karya Tulis Ilmiah

Guru MTs DDI Padanglampe Kabupaten Pangkep.

\section{DAFTAR PUSTAKA}

Aina, M., Bambang, H., Retni, S. B., Afreni, H., \& Sadikin, A. (2015). Pelatihan Penulisan Karya Tulis Ilmiah bagi Guru-Guru SMA 8 Kota Jambi. Jurnal pengabdian pada masyarakat, 30(3), 29-32.

Anggoro, S., Harmianto, S., \& Yuwono. (2018). Upaya Meningkatkan Kemampuan Pedagogik Guru melalui Pelatihan Pembelajaran Tematik Sains Menggunakan Inquiry Learning Process dan Science Activity Based Daily Life. JPPM (Jurnal Pengabdian dan Pemberdayaan Masyarakat), 2(1),29-35.

Kunandar. 2011. Guru Profesional: Implementasi Kurikulum Tingkat Satuan Pendidikan (KTSP) dan Sukses dalam Sertifikasi Guru. Jakarta: Rajawali Pers.

Mansyur, U. (2016). Inovasi Pembelajaran Bahasa Indonesia melalui Pendekatan Proses. RETORIKA: Jurnal Bahasa, Sastra, dan Pengajarannya,9(2), 158163.

Mansyur, U. (2013)Evaluasi Kompetensi Pedagogik Guru Bahasa Indonesia SMP Peserta MGMP dan yang Bukan Peserta MGMP di Kabupaten Pinrang.Thesis: Universitas Negeri Makassar.

Mansyur, U. (2018). Pembelajaran Inovatif Bahasa Indonesia di Sekolah Dasar. INA-Rxiv, https://doi.org/10.31227/osf.io/fyr8g, Diakases 1 Mei 2018).
Mulyasa, E. (2011). Standar Kompetensi dan Sertifikasi Guru. Bandung: RemajaRosdakarya.

Musfah, J. (2011). Peningkatan KompetensiGuru:MelaluiPelatihanda nSumber Belajar Teori dan Praktik. Jakarta: Kencana.

Peraturan Menteri PAN-RB Nomor 16 Tahun 2009 tentang Jabatan Fungsional dan Angka Kreditnya.

Tanjung, B.N.\& Ardial. (2013). Pedoman Penulisan Karya Ilmiah: Proposal, Skripsi, dan Tesis. Jakarta: Kencana. 